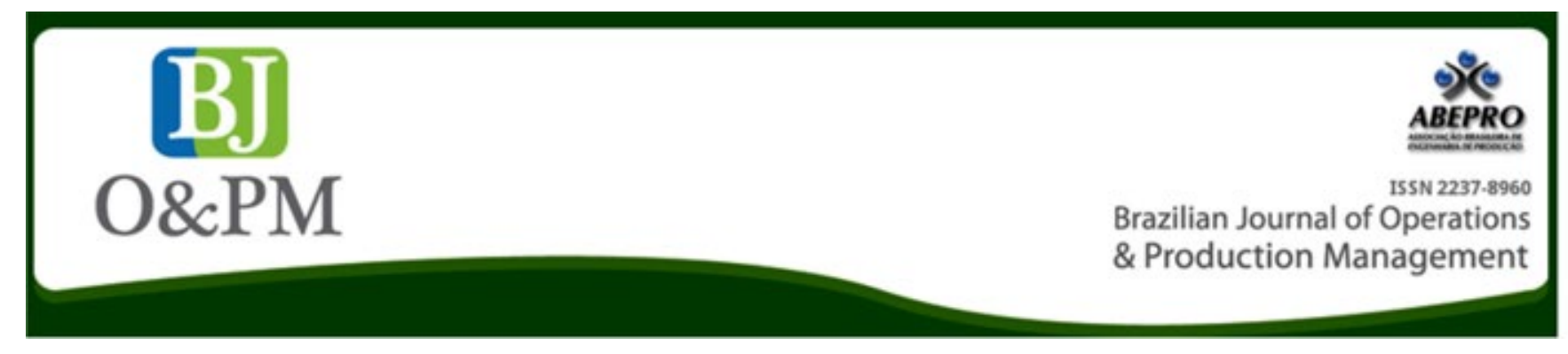

\title{
SUBJECTIVITY OF APPRAISALS OF INVENTIVE STEP IN PATENT EXAMINATIONS AS AN ELEMENT OF UNCERTAINTY IN THE POTENTIAL FOR TECHNOLOGICAL INNOVATION
}

\author{
Cesar Vianna Moreira Junior ${ }^{1}$, Maria Ângela de Souza Fernandes ${ }^{1}$, Ricardo Carvalho Rodrigues ${ }^{1}$, \\ Adelaide Maria de Souza Antunes ${ }^{1}$, Sergio Paulino de Carvalho ${ }^{1}$
}

1 National Institute of Industrial Property - INPI

\begin{abstract}
How likely is an invention to turn into an innovation in the short, medium, and long term? Do patent examiners have the power to influence the direction technology takes in a given sector or industry? This study discusses possible impacts arising from the interpretation of the concept of inventive step on the potential for innovation in the electricity area. It also aims to identify any indications of subjectivity in the concept of "inventive step," of the examiners' decision-making power, and the influence of the examiners' evaluations on the direction of technology in the light of the concepts of conformity of action by agents to institutional rules and room for deviation as proposed by Dequech (2013). A case study is presented, comparing the content of first instance examinations and appeal examinations of patent claims in the area of electricity from 2015 to 2017, showing the levels of divergence in the appraisals of inventive step and recommendations for initial decisions to be reversed.
\end{abstract}

Keywords: Invention Patent; Inventive Step; Innovation; Technological Development. 
Brazilian Journal of Operations \& Production Management

Volume 14, Número 4, 2017, pp. 519-528

DOI: 10.14488/BJOPM.2017.v14.n4.a8

\section{INTRODUCTION}

Companies the world over are in competition in their respective industries for the intensity and ownership of innovations. To compete for a successful future, it is necessary to understand how competing for the future differs from competing for the present. New industries are emerging and existing ones are going through profound transformations. The rules for how to seize opportunities in emerging technologies are still being written, while the rules for existing sectors have to be reviewed. In 2017, Brazil was ranked $61^{\text {st }}$ in the world competitiveness ranking of 63 countries compiled by the International Institute for Management Development in partnership with Fundação Dom Cabral, ahead only of Venezuela and Mongolia. Is finding solutions for technical problems the driving force for inventors, innovators, and engineers? Is it worth pursuing the debate on innovation intensity and technological change separately from investments in R\&D and their effectiveness? Innovation has to do with knowledge; however, t when knowledge is transferred, control-related risks are raised and the authorship of such knowledge and novel components of technologies has to be protected (Folha de São Paulo, 2017; Prahalad et Hamel, 2005; Kupfer et Hasenclever, 2013).

The Instituto Nacional da Propriedade Industrial (INPI National Institute of Industrial Property) is the entity responsible for executing the standards that regulate intellectual property in Brazil, and patents are tools that, among others, secure intangible assets. To give an idea of the size of the current patenting system, recent data published by INPI show that, between 2011 and 2014, an average of 33,000 patent applications were filed every year. In the electricity area alone, 1,800 patent applications were filed, each year in the same period, and there were around 12,000 applications in the examination pipeline, making this one of the areas with most patenting activity in Brazil. For a patent to be granted by a state, the invention must meet some basic requirements; namely, it must be novel (i.e. it must not reproduce existing art); it must involve an inventive step (i.e. it must not be evident or obvious from prior art to a person skilled in the art); it must be susceptible of industrial application (i.e. it must be possible to produce it on an industrial scale).

The need for patents to contain an inventive step is established in Article 27 of the Agreement on Trade-Related Aspects of Intellectual Property Rights (TRIPS Agreement); however, it does not establish what level of invention is required, giving the examiners, working in each technological area, a degree of subjective leeway. If the requirements are fulfilled and patent protection is granted, the secret must be revealed. The examination of patent applications depends on an effective search for prior art, which itself demands a good understanding in terms of the technology contained in the claims. In other words, the examiner's experience is paramount for their decisions to be balanced and for the same criteria to be applied across all patent applications. The technical competence of the examiners is assured by the requirement that they compete in a public examination to join INPI and then receive specific training in-house for, at least, a year. Their role is essentially technical, insofar as it involves analyzing the patentability of the claimed inventions. Substantive examinations must observe the provisions of the Brazilian Industrial Property Law, and the examiners' decisions are made public. INPI publishes the reports based on the examinations of all patent claims on its online patent system (http://eparecer.inpi.gov.br/eparecer.php).

The aim of this study is to investigate the subjectivity of the concept of inventive step and how the INPI examiners' evaluations of inventiveness may affect the potential for technological innovation in the area of electricity. A critical analysis is conducted concerning the requirement for inventive step in the granting patent's process - considering the content of appeal decisions and corresponding first instance examination reports - focusing on technological innovations and developments in the electricity sector in Brazil. The questions to be addressed are: "Is the concept of inventive step objective?" and "To what extent could the interpretation of inventive step in evaluations of patentability influence the potential for technological innovation in the Brazilian electricity sector?"

\section{LITERATURE REVIEW}

\section{Technology, Innovation, and Development}

As a driver of economic dynamism, technology draws on a variety of areas of knowledge. When new technologies emerge (new processes, techniques, or products), it is in the interests of companies to exploit them (apply the inventions commercially) in order to change their technological paradigm $^{1}$ and technological trajectories ${ }^{2}$. Technological change is normally attributed to economic developments driven by market needs (demand-pull model) or the emergence of new technologies, which, themselves, drive economic developments into the sector (technology-push model) (Tigre, 2006; Dosi, 1982).

1 A technical problem-solving "model" or "pattern" selected according to principles that derive from scientific knowledge and production practices.

2 The direction of a technological process within a paradigm, which is directly influenced by technological and economic variables. 


\section{Institution, Conformity, and Room for Deviation}

Investing in innovation brings many uncertainties, opening room for public interventions designed to induce companies to experiment, find, and introduce new products, services, and processes that outperform the ones existing in their market. The market acts in selecting amongst its agents, while the state has the role of broadening the intensity of the selection process by creating institutions that facilitate the creation and spread of new technologies (Kupfer et Hasenclever, 2013).

Institutions are socially and historically constructed regulators of behavior that shape and organize interactions between individuals, setting relatively stable socially shared standards, rules of thinking and conduct. They are also responsible for imposing coercive norms, moral values, incentives, customs, habits, cognitive structures, and tacit skills and capabilities, which generate regularity of conduct. These include formal dimensions derived from legal standards and informal aspects derived from social norms and conventions. There is a difference between the conscious and unconscious observance of rules. The notions of thinking habits, path dependence, and transaction costs help build up a broader and more complex view of the modus operandi of institutions in society, and are fundamental categories in institution-oriented approaches, demonstrating the various dimensions involved in comprehending the complex choices and behaviors of subjects, the ways institutions change or resist change, and development processes in each society (Ponde, 2005; Pamplona, 2010; Dequech, 2013).

Dequech (2013) proposes an explanation for how institutions influence individual thinking and behavior and shows that there is a difference between the conscious and unconscious observance of institutional rules. Conformity with a given institution could equally be the outcome of habits adopted socially (rather than a conscious decision to act or think in a given way) or of situations where agents follow the rules prescribed by institutions consciously. Habits are formed through the repetition of behaviors and thoughts, and may originate from unconscious imitation or conscious repetition. When agents comply with a norm only because of the threat of potential external sanctions, this indicates they have not internalized this norm and do not even recognize it as legitimate.

According to Dequech, conformity may be explained by asymmetries of information and the perception of and aversion to uncertainty. An agent may consider the uncertainty of the outcome of an unconventional action to be too high for them to be willing to adopt deviant behavior. Conformity could, then, be a practical response to a complex situation (vis-à-vis agents' competences and/or resources), where the cost and effort of seeking out alternatives are high.
Legitimacy - compatibility with socially accepted values - is another explanation for conformity with institutional rules. Legitimacy has to do with the process and consequences of explaining choices to others. The expectation of having to explain or justify decisions can influence the decision-making process.

Another possible explanation for conformity is that the widespread adoption of a given pattern of behavior or thinking can make this behavior or thinking seem natural or even inevitable. There may be situations where an agent would wish to behave differently from their peers or even wish everyone in the group would behave differently, but they end up doing things the same way as ever. In such a situation, an alternative action is envisaged but not taken. This is because of a lack of practical means to pursue such an alternative course of action, which implies a lack of both power and resources to adopt the deviant behavior (Dequech, 2013).

\section{Analysis of the Concept of Inventive Step - TRIPS and Brazilian Industrial Property Law}

Brazil is a signatory to the Agreement on Trade-Related Aspects of Intellectual Property Rights (TRIPS Agreement) as a member of the World Trade Organization (WTO). With regard to patentable subject matter, article 27, paragraph 1 of the TRIPS Agreement states that the following:

Subject to the provisions of paragraphs 2 and 3 , patents shall be available for any inventions, whether products or processes, in all fields of technology, provided that they are new, involve an inventive step and are capable of industrial application (Brasil, 1994).

According to Abrantes (2011), the role of examiners is essentially technical, in that they are responsible for verifying the novelty, inventive step, industrial application, and detailed disclosure of the patent application. The TRIPS Agreement (Article 27) establishes the need for patents to contain an inventive step, but nowhere does it state what level of inventiveness is required, which, in theory, opens room for countries to decide how strictly to apply the inventive step rule per area of technology according to their industrial policies.

The TRIPS Agreement states the need for an "inventive step" before an invention patent can be granted, without, however, proposing a clear, objective definition or specific concept for what such a step might be or what level of inventiveness is required by the signatory countries in their examinations of patents.

In order to fulfill the basic requirements of the TRIPS Agreement and regulate the other specific issues related 
to intellectual property in Brazil, Law No. 9,279, known as the Industrial Property Law, was approved on May 14, 1996. Article 2 of this law states that:

The protection of rights relating to industrial property, considering its interest to the society and the technological and economic development of the country, is provided through: I - the granting of invention patents and utility models (Brasil, 1996).

Notably, in this law, a patent is described as an instrument of significant importance for supporting the country's economic and technological development, providing for the exclusivity of sales of the innovation to its holder, which certainly results in competitive advantages for companies engaged in developing innovations and new technologies in the country.

Article 8 of the Industrial Property Law states that "any invention that fulfills the requirements of novelty, inventive step, and industrial application is patentable" (Brasil, 1996), while Article 13 of the same law states that "an invention is endowed with inventive activity whenever, for a person skilled in the art, it cannot be derived evidently or obviously from the existing art" (Brasil, 1996).

According to the Comments on the Industrial Property Law, published by Instituto Dannemann Siemsen de Estudos em Propriedade Intelectual (Dannemann Siemsen Institute for Intellectual Property Studies), inventive activity may be ascertained if a person skilled in the subject, in possession of the prior documents that are most similar to the invention and its savoir faire, is unable to reach the solution proposed in the claim (IDS, 2005, p. 35).

There are some comparative studies on the application of the inventive step concept at the leading international patent offices, such as those in the United States (USPTO), Japan (JPO), and Europe (EPO). A study on these three offices (Kunin et Signore, 2008) examined how the patent offices make decisions for a given invention and the way the concept of the inventive step is applied in the substantive examination process for patents. The study found that much "disharmony" exists and there are some conceptual and methodological differences in the enforcement of the requirement for inventive step throughout the substantive examination for patent claims. The differences in the strictness observed in each country's substantive examinations could potentially translate into different decisions about the patentability of a given claim in different countries.

\section{METHODOLOGY}

A case study was conducted, analyzing appeal decisions and the corresponding first instance examination reports relating to patent claims from the electricity area, making a detailed comparison of their content and directly consulting the examiners involved in the reexamination with the main aim of ascertaining any divergences in the application of the concept of inventive step and recommendations for the initial decision to be reversed.

According to Yin (2005), "a case study is an empirical inquiry that investigates a contemporary phenomenon in depth and within its real-life context, especially when the boundaries between phenomenon and context are not clearly evident." In the next stage of the research, in order to reinforce the indications and impressions gathered in the first stage, as well as obtaining complementary information, a sensitivity analysis of the study cases considered in the first phase, addressing the conformity of the agents' actions with the institutional rules and room for deviation, was conducted, as explained by Dequech (2013), drawing on the following criteria: uncertainty aversion, legitimacy, naturality/ inevitability, and deviant behavior.

\section{Case Study - Electricity Sector}

The initial source of data for this study were the reports of the technical appeal examinations made in response to rejections of claims for the patenting of inventions in the area of electricity examined by INPI between May 2015 and May 2017. The corresponding first instance decisions were also consulted. At the end of the data collection stage, a total of 100 refused claims whose applicants filed for appeal had been gathered.

The content of all the reports from the initial examination process and the appeal process was investigated, aiming to effectively compare the results and ascertain any reverted decisions, divergences in appraisals of the inventive step, and situations where, although the claims were abandoned after the first examination stage, the applicants subsequently appealed against the INPI decision.

It is worth noting that the examiners were themselves consulted/interviewed in order to clear up queries and confirm the understandings and impressions gleaned in the study.

The following comments and assumptions should be noted before the findings are presented:

- $\quad$ The electricity division currently has 17 examiners. In the case of the data evaluated here, the first exam- 
inations were conducted by 13 examiners (referred to here by the letters $A$ to $M$ ) - the total number of examiners in the group minus managers, very new examiners (for whom not enough time had elapsed for their initial examinations to be appealed), and examiners on leave;

- In the appeal stage, the assessment of patentability has to be done by an examiner different from the one responsible for the initial examination;

- Six examiners (here referred to by the letters A to F) were responsible for examining all the appeals concerning patent claims in the electricity area. These six examiners had all been working at INPI for the same length of time and had received exactly the same in-house training, making them a reliable, homogeneous sample for the purposes of this study.

The analysis covers five possible alternatives - four main ones and an extra one, as shown below:

- Alternative 1: with a divergence of opinion (about the inventive step) and with a recommendation for the reversal of the initial decision (yes \& yes);

- Alternative 2: with a divergence of opinion but no recommendation for the reversal of the initial decision (yes \& no);

- Alternative 3: with no divergence and with a recommendation for the reversal of the initial decision (no \& yes);

- Alternative 4: with no divergence but no recommendation for the reversal of the initial decision (no \& no); and

- Alternative 5: a first office action was issued after the first instance examination, but the applicant did not reply to this; however, after the case was abandoned because of failure to reply to the office action, we found out that the applicant filed an appeal against the decision.

\section{Sensitivity Analysis of the Case Studies}

In order to make a more in-depth critical analysis of the role of the examiner in ascertaining the "inventive step" in claimed inventions filed for patent protection, the conformity of their actions with the rules of the institution and their room for deviance (Dequech, 2013) were observed, drawing on the concepts of uncertainty aversion, legitimacy, naturality/inevitability, and deviant behavior. The analysis was designed to shed more light on the different rationales behind the behavior of the six examiners responsible for the reexaminations of the claims after they had been rejected on the grounds of their inventive step (conformity) to ascertain whether they upheld the rejection (compliant behavior) or whether they reversed the decision (deviant behavior).

Using the aforementioned concepts, hypotheses about the four alternatives presented in the previous phase were formulated. Based on these hypotheses, logical propositions were established and the alternatives were analyzed using the criteria of uncertainty, legitimacy, naturality, and deviant behavior (see Table 10, Sensitivity Analysis).

\section{RESULTS AND DISCUSSION}

It was found that there were clear recommendations for the initial decisions to be reversed by the appeal examiners in $37 \%$ of the cases (see Table 1 ). However, in only $28 \%$ of the cases was there an actual divergence in the evaluation of the inventive step per se. In other words, the cases of reversed decisions or recommendations for their reversal were far from being all down to divergences in the evaluation of the inventive step. As such, for a more detailed analysis, it was necessary to probe the data in greater depth, highlighting analyses of specific cases.

Table 1. Data on Initial Examiners

\begin{tabular}{|c|c|c|c|}
\hline Primary Examiner & $\begin{array}{c}\text { Number of } \\
\text { Appeals } \\
\text { Analyred }\end{array}$ & $\begin{array}{c}\text { Number of Reversals } \\
\text { and } \\
\text { Recommendations for } \\
\text { Reversal }\end{array}$ & $\begin{array}{c}\text { Total Divergences in } \\
\text { Evaluations of } \\
\text { Inventive Step }\end{array}$ \\
\hline A & 24 & 14 & 13 \\
\hline B & 15 & 1 & 1 \\
\hline C & 13 & 6 & 3 \\
\hline D & 11 & 4 & 3 \\
\hline C & 10 & 7 & 4 \\
\hline F & 6 & 1 & 0 \\
\hline G & 4 & 2 & 1 \\
\hline H & 4 & 0 & 0 \\
\hline I & 4 & 0 & 0 \\
\hline J & 4 & 0 & 0 \\
\hline K & 3 & 0 & 1 \\
\hline L & 1 & 1 & 1 \\
\hline M & 1 & 1 & 28 \\
\hline Total & 100 & 37 & \\
\hline & & & \\
\hline
\end{tabular}

Source: own research

Figure 1 illustrates the occurrence of alternatives 1, 2, 3, and 4 as proportions of the total number of appealed claims. Each of the alternatives is discussed in greater detail below.

In alternative 1 (yes \& yes), there were divergences in the examiners' appraisals of the inventive step and this was what resulted in the initial rejection being reversed (or for this to be recommended). Once a divergence has been identified, it tends to result in the reversal (or at least the recommendation for the reversal) of the initial decision. Of the cas- 
B Brazilian Journal of Operations \& Production Management Volume 14, Número 4, 2017, pp. 519-528

DOI: 10.14488/BJOPM.2017.v14.n4.a8 es with divergences of opinion, this, which is borne out by figures 2 and 3, was the alternative that was expected to be more commonplace. In $28 \%$ of the appeals analyzed there was some divergence of opinion, and 24 (86\%) of these 28 divergences fitted into alternative 1.

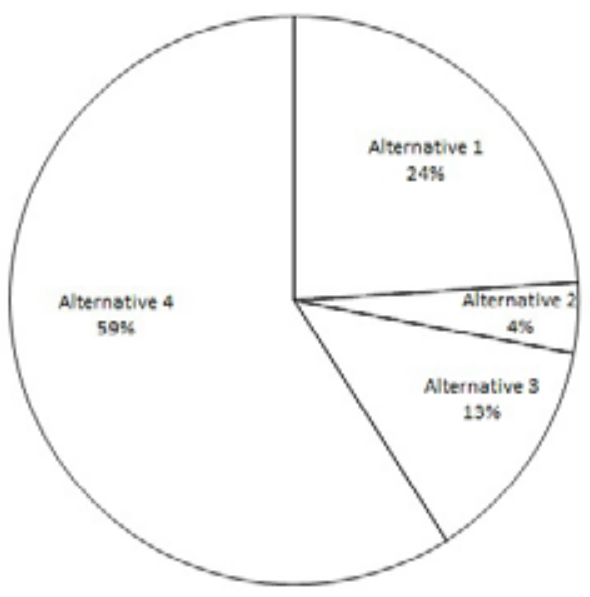

Figure 1. Percentage of each of the four alternatives compared to the total number of cases analyzed.

Source: own research

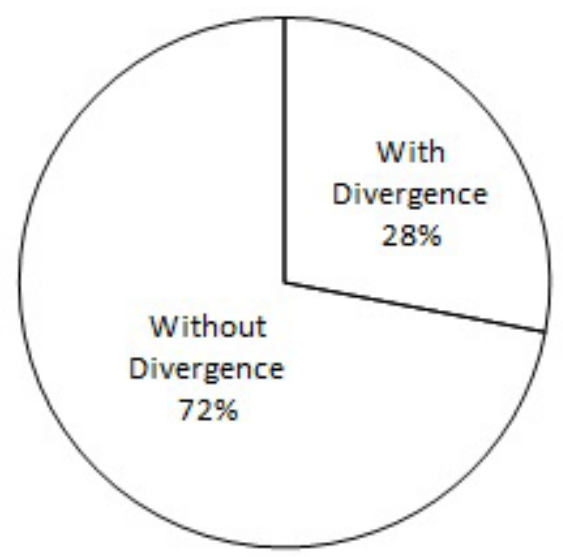

Figure 2. Percentage of cases with and without divergence of opinions about inventive step

Source: own research

In the alternative 2 (yes \& no) cases, divergences of opinion were observed in the analyses of the inventive step, but the initial examiners' decisions were not reversed (or recommended to be reversed). At first sight, this might appear inconsistent, but there are situations where an examiner, precisely because he/she diverges in opinion, sees the need for complementary searches, making it impossible for the first instance decision to be maintained, based only on the initial search. In these situations, more energy is expended by the examiner, because while upholding the initial decision, they are obliged to make more searches and conduct new stages of examination. However, cases like these accounted for just $4 \%$ of all the cases analyzed, as shown in Figure 1 above.

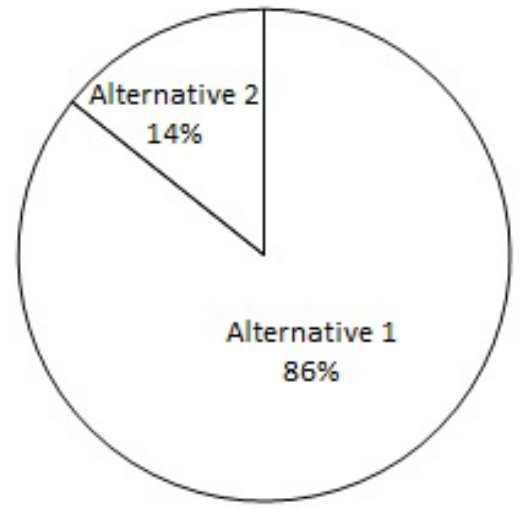

Figure 3. Percentage of alternatives 1 and 2 in all the cases with divergences of opinion

Source: own research

In alternative 3 (no \& yes), the appeal examiner did not diverge with the primary examiner in his/her opinion about the inventive step, but did reverse (or recommended the reversal of) the initial decision. At first sight, reversing a decision without diverging in opinion may seem incoherent; however, this can happen when the appellant has submitted new arguments or made modifications to the patent claim. Occurrences of this kind accounted for $13 \%$ of the total analyzed (see Figure 1).

In alternative 4 (no \& no), there was no divergence of opinion between the two examiners about the inventive step of the claimed invention; thus, there was no reversal (or no recommendation for reversion) of the initial decision. As in alternative 1, if we assume that divergences and agreements were duly identified, such a situation tends to result in confirming the initial decision. Figure 4 shows the percentage of cases of alternatives 3 and 4 from the total cases with no divergence of opinion.

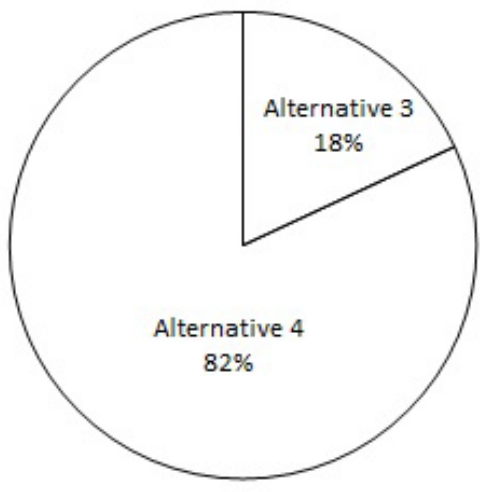

Figure 4. Percentage of cases of alternatives 3 and 4 from the total cases with no divergence of opinion

Source: own research 
In alternative 5 (extra), after the first office action in the first instance was published, the applicant did not reply. However, despite the refusal of the patent based on lack of response by the applicant in the first instance, it was found that the applicants subsequently filed an appeal against this decision. This may appear incoherent, but there are two potential explanations: the applicant may simply have missed the deadline for responding to the office action, or they may have done so intentionally in the hope that an appeal examination would be more favorable, since appeals must be examined by a different examiner than the initial one. This alternative accounted for $4 \%$ of the cases examined.

Table 2 sums up the distribution of cases according to whether or not the initial decision was reversed in the appeal and whether or not there was a divergence of opinion between the initial and appeal examiners.

Table 2. General data on divergences of opinions on inventive step and reversals or recommendations for the reversal of decisions

\begin{tabular}{|c|c|c|c|}
\hline \multirow{2}{*}{\multicolumn{2}{|c|}{ General }} & \multicolumn{2}{|c|}{ Reversal/Recommendation for Reversal } \\
\hline & & Yes & No \\
\hline \multirow{2}{*}{ Divergence } & Yes & 24 & 4 \\
\hline & No & 13 & 59 \\
\hline & & 37 & \\
\hline
\end{tabular}

\section{Source: own research}

Tables 3 to 9 show the divergences between the appeal and initial examiners.

Table 4. Divergences in opinion of examiner A.

\begin{tabular}{|c|c|c|c|c|}
\hline \multicolumn{2}{|c|}{ A } & \multicolumn{2}{c|}{ Reversal/Recommended Reversal } & \\
\cline { 3 - 4 } & yes & No & Total \\
Divergence & Yes & 3 & 2 & Divergences \\
\cline { 3 - 4 } & No & 3 & 12 & 5 \\
\hline & & Total Reversions & 6 & \\
\cline { 3 - 4 } & &
\end{tabular}

Source: own research
Table 5. Divergences in opinion of examiner B.

\begin{tabular}{|c|c|c|c|c|}
\hline \multicolumn{2}{|c|}{ B } & \multicolumn{2}{c|}{ Reversal/Recommended Reversal } & \\
\cline { 3 - 4 } & yes & No & Total \\
Divergence & Yes & 4 & 1 & Divergences \\
\cline { 2 - 4 } & No & 1 & 13 & 5 \\
\hline
\end{tabular}

Source: own research

Table 6. Divergences in opinion of examiner C.

\begin{tabular}{|c|c|c|c|c|}
\hline \multirow{2}{*}{\multicolumn{2}{|c|}{ C }} & \multicolumn{2}{|c|}{ Reversal/Recommended Reversal } & \multirow{3}{*}{$\begin{array}{c}\text { Total } \\
\text { Divergences }\end{array}$} \\
\hline & & yes & No & \\
\hline \multirow{2}{*}{ Divergence } & Yes & 8 & 0 & \\
\hline & No & 6 & 4 & 8 \\
\hline & & Total Reversions & 14 & \\
\hline
\end{tabular}

Source: own research

Table 7. Divergences in opinion of examiner D.

\begin{tabular}{|c|c|c|c|c|}
\hline \multicolumn{2}{|c|}{ D } & \multicolumn{2}{c|}{ Reversal/Recommended Reversal } & \\
\cline { 3 - 4 } & yes & No & Total \\
Divergence & Yes & 3 & 1 & 4 \\
\cline { 2 - 4 } & No & 1 & 12 & 4 \\
\hline
\end{tabular}

Source: own research

Table 8. Divergences in opinion of examiner E.

\begin{tabular}{|c|c|c|c|c|}
\hline \multicolumn{2}{|c|}{$E$} & \multicolumn{2}{c|}{ Reversal/Recommended Reversal } & \\
\cline { 3 - 4 } & yes & No & $\begin{array}{c}\text { Total } \\
\text { Divergences }\end{array}$ \\
\hline \multirow{2}{*}{ Divergence } & Yes & 5 & 0 & 5 \\
\cline { 2 - 4 } & No & 1 & 8 & \\
\cline { 3 - 4 } & & Total Reversions & 6 & \\
\cline { 3 - 4 } & &
\end{tabular}

Source: own research

Table 9. Divergences in opinion of examiner $\mathrm{F}$.

\begin{tabular}{|c|c|c|c|c|}
\hline \multicolumn{2}{|c|}{$F$} & \multicolumn{2}{c|}{ Reversal/Recommended Reversal } & \\
\cline { 3 - 5 } & yes & No & Total \\
Divergence & Yes & 1 & 0 & Divergences \\
\cline { 2 - 5 } & No & 1 & 10 & 1 \\
\hline
\end{tabular}

Source: own research

Table 3. General data on appeal examiners

\begin{tabular}{|c|c|c|c|}
\hline \multicolumn{5}{|c|}{ Appeal Examiners (ordered by number of appeals examined) } \\
\hline Examiner & No. of Appeals & Total Reversions/Recommendations & Total Divergences \\
\hline A & 20 & 6 & 5 \\
\hline B & 19 & 5 & 5 \\
\hline C & 18 & 14 & 8 \\
\hline D & 17 & 4 & 4 \\
\hline E & 14 & 6 & 5 \\
\hline F & 12 & 2 & 1 \\
\hline Total & $\mathbf{1 0 0}$ & $\mathbf{3 7}$ & $\mathbf{2 8}$ \\
\hline
\end{tabular}

Source: own research 
From tables 3 to 9 it can be seen that, although there were no great discrepancies in the recommendations for reversals of decisions and/or divergences of opinion between examiners $A$ to $F$, there was also no perfect equilibrium. This corroborates the indications of subjectivity already observed in the analysis of alternatives 1 to 4 and the rates of divergence encountered.

Overall, it was found that $37 \%$ of the patent applications filed in the area of electricity were reversed in the appeal process and $28 \%$ of the cases contained divergences of opinion as to the existence of an inventive step.

Some more in-depth comments about alternatives 2 and 3 are required. In alternative 2 (yes \& no), there are cases where there was a divergence of opinion over the existence of an inventive step in the claimed invention; however, the initial decision was not reversed (and there was no recommendation for its reversal). As mentioned earlier, there are situations when an examiner sees potential for a divergent opinion and therefore sees the need for complementary searches, deciding it is impossible to uphold the first decision on the grounds of the initial search alone. In these cases, the examiner exerts extra energy, because, even if they uphold the original decision, they must make new searches and undertake new stages of examination. However, cases such as these only accounted for $4 \%$ of the total analyzed. Nonetheless, it is recommended that measures be adopted such as on-the-job training, alignment of the training of different teams, and the optimization of the distribution of the patent claims per classification/area of knowledge of the examiners so that the number of such occurrences can gradually be reduced.

In the case of alternative 3 (no \& yes), there was no divergence in the analysis of the inventive step, but the decision was reversed (or its reversal was recommended). This kind of situation occurs when the appellant introduces new arguments or alters the claims. Cases of this kind accounted for $13 \%$ of the total analyzed. Although, at first sight, they may appear incoherent, despite appearing in good number, they are part and parcel of the examination/appeal process per se.

As for the appeal examiners, examiners $C$ and $E$ were found to be responsible for the highest percentage of reversed decisions ( $78 \%$ and $43 \%$, respectively) - higher than the $37 \%$ average for the area as a whole. It was also found that the examiners who examined the alternative 3 cases (i.e. who had to conduct extra examinations above the average of the $4 \%$ divergences of opinions and recommendations for reversal) analyzed a high percentage of appeals coming from primary examiners with a different profile. It is worth remembering that all the examiners had almost identical experience and length of employment at INPI and had been trained in the same way in the same group in house. However, the first instance examiners had been trained much longer ago and in different groups, which may explain cases of divergence.

\section{Sensitivity Analysis of the Cases under Study}

According to Dequech (2013), the higher the uncertainty aversion, legitimacy, and naturality/inevitability, the more conformity there will be, making deviant behavior less common or less marked. In the alternatives studied here, deviant behavior would be when an appeal examiner diverged in opinion from the first instance examiner, potentially reversing his decision. Some hypotheses concerning these circumstances are therefore proposed:

(1) If there is a divergence or recommendation for a reversal of opinion, then legitimacy and naturality (inevitability) are weak;

(2) Consequently, if legitimacy or naturality (inevitability) is not weak, there is no divergence or recommendation for a reversal of opinion;

(3) If a diversion and recommendation for a reversal of opinion occur together, there is low uncertainty aversion and intense deviance of behavior;

(4) Consequently, if uncertainty aversion is moderate or intense or deviant behavior is weak or moderate, there is no divergence or no recommendation for a reversal of opinion; and

(5) If there is no divergence or recommendation for a reversal of opinion, then uncertainty aversion is not weak and deviance of behavior is not strong.

As a result of these five hypotheses:

1) From hypothesis 1 it can be inferred that legitimacy and naturality (inevitability) are weak in alternatives 1, 2, and 3;

2) From hypothesis 2 it can be inferred that legitimacy and naturality (inevitability) are moderate or intense in alternative 4;

3) From hypothesis 3 it can be inferred that uncertainty aversion is weak and deviance of behavior is intense in alternative 1 ; 
Table 10. Sensitivity Analysis (intense, moderate, weak) using the criteria of uncertainty, legitimacy, naturality, and deviant behavior

\begin{tabular}{|l|c|c|c|c|c|c|}
\hline $\begin{array}{c}\text { Alternatives } \\
\text { Under Study }\end{array}$ & Divergence & $\begin{array}{c}\text { Reversal } \\
\text { Recommended } \\
\text { Reversal }\end{array}$ & $\begin{array}{c}\text { Uncertainty } \\
\text { Aversion }\end{array}$ & Legitimacy & $\begin{array}{c}\text { Naturality / } \\
\text { Inevitability }\end{array}$ & $\begin{array}{c}\text { Deviance of } \\
\text { Behavior }\end{array}$ \\
\hline Alternative 1 & Yes & Yes & Weak (3) & Weak (1) & Weak (1) & Intense (3) \\
\hline Alternative 2 & Yes & No & Moderate (4) & Weak (1) & Weak (1) & Moderate (4) \\
\hline Alternative 3 & No & Yes & Moderate (4) & Weak (1) & Weak (1) & Moderate (4) \\
\hline Alternative 4 & No & No & Intense (5) & Intense (2) & Intense (2) & Weak (5) \\
\hline
\end{tabular}

Source: own research based on criteria obtained from Dequesch (2013) and data obtained in the field

4) From hypothesis 4 it can be inferred that uncertainty aversion is moderate or intense and deviance of behavior is weak or moderate in alternatives 2 and 3; and

5) From hypothesis 5 it can be inferred that uncertainty aversion is moderate or intense and deviance of behavior is weak or moderate in alternative 4.

Table 10 illustrates the sensitivity analysis described above.

From the findings shown in Table 10, a few analyses about the alternatives under study can be proposed. In Alternative 1 , when there was a divergence of opinion and a recommendation for the initial decision to be reversed, there was clearly deviant behavior on the part of the appeal examiner, which is consistent with the finding that this was indeed intense. In Alternative 2, although there was a divergence of opinion about the inventive step in the claim, no recommendation was made for the decision to be reversed. In other words, although deviance was clearly present, it was partial, which is consistent with its strength being evaluated as "moderate." In Alternative 3, although the second examiner recommended reversing the initial opinion, there was no divergence over the inventive step in the claim, in which case there was again some deviant behavior, but not so strong as to be more than the "moderate" found in the analysis. Finally, in Alternative 4, where there was neither divergence of opinion nor a recommendation for a reversal of opinion, there was no deviant behavior, or this was masked, which is consistent with the "weak" intensity applied to this category. Consistent with the aim that examiners' analyses be homogeneous, this was the case expected to yield the lowest level of deviant behavior and the highest number of occurrences in all, which was borne out in the sensitivity analysis (Table 10: weak) and the study (Figure 1: 59\%).

\section{CONCLUSIONS}

During the study of patenting in the area of electricity, it was found that $37 \%$ of the claims were reversed by the appeal process, and in $28 \%$ of the cases there was a diver- gence between the initial and the appeal examiners as to the evaluation of the inventive step. In other words, even in a given area with highly trained professionals, there are still divergences about the inventive step analysis.

After the sensitivity analysis using the criteria of uncertainty, legitimacy, and naturality, clear evidence of deviant behavior was encountered on the part of the examiners in all the alternatives studied. In $41 \%$ of the cases, the deviant behavior was moderate or strong, while in the remaining $59 \%$ it was judged to be weak.

As such, it can be inferred that there is subjectivity in the concept of the inventive step and this grants patent examiners legitimate decision-making power. Rationality and irrationality are not just a matter of present and future, since they also involve potential futures.

Future studies could replicate this kind of approach in other areas of technology and develop a methodology for qualitatively evaluating the data obtained, possibly using interviews/ questionnaires or artificial intelligence tools, such as fuzzy logic.

\section{REFERENCES}

Abrantes, A. C. S. (2011), Introdução ao sistema de patentes - Aspectos técnicos, institucionais e econômicos, Lumen Juris, Rio de Janeiro, RJ.

Brasil (1994), Decreto no 1.355, de 30 de dezembro de 1994, Acordo sobre Aspectos dos Direitos de Propriedade Intelectual Relacionados ao Comércio - TRIPS, Available at <http://www.inpi.gov.br/legislacao-1/27-trips-portugues1. pdf>. Accessed on June 15, 2017.

Brasil (1996), Lei no 9.279, de 14 de maio de 1996, Regula direitos e obrigações relativos à propriedade industrial, Available at <http://www.planalto.gov.br/ccivil_03/leis/L9279. htm $>$ Accessed on June 1, 2017.

Dequech, D. (2013), “Economic institutions: explanations for conformity and room for deviation", Journal of Institutional Economics, Vol. 9, pp 81-108

Dosi, G. (1982), "Technological paradigms and technological trajectories: a suggested interpretation of the determi- 
nants and directions of technical change", Research Policy, Vol. 11, pp.147-162.

Folha de São Paulo (2017), Brasil só ganha em competitividade de Mongólia e Venezuela, mostra ranking, Available at <http://www1.folha.uol.com.br/ mercado/2017/05/1888626-brasil-so-ganha-em-competitividade-de-mongolia-e-venezuela-mostra-ranking. shtml?cmpid=newsfolha $>$ Accessed on May 31, 2017

Instituto Dannemann Siemsen de Estudos de Propriedade Intelectual - IDS (2005), Comentários à Lei da Propriedade Industrial, Renovar, Rio de Janeiro. 2005.

Instituto Nacional da Propriedade Intelectual - INPI (BR) (2013), Resolução no 124, de 04 de dezembro de 2013, Institui diretrizes de exame de pedidos de patente, Brasília, DF.

Kunin, S.G.; Signore, J.C.P. (2008), A Comparative Analysis of the Inventive Step Standard in the European and Japanese Patent Offices from a US Perspective, IP Litigator, Jan./Feb.
Kupfer, D.; Hasenclever, L. (2013), Economia industrial. Fundamentos teóricos e práticas no Brasil, 2 ed., Campus/Elsevier, Rio de Janeiro.

Pamplona, K. M. (2010), “Uma interação entre hábitos, path dependence e custos de transação para compreensão da mudança social e do desenvolvimento em cada sociedade: abordagens institucionalistas", Revista Ágora, Vol. 5, No. 1. pp.04-22.

Ponde, J.L. (2005), "Instituições e Mudança Institucional: uma Abordagem Schumpeteriana", Revista Economia, Vol. 6, No. 1, pp. 119-160.

Prahalad, C.K.; Hamel, G. (2005), Competindo pelo futuro: estratégias inovadoras para obter o controle do seu setor e criar os mercados de amanhã, 24 ed., Elsevier, Rio de Janeiro, RJ.

Tigre, P. B. (2006), Gestão da inovação: a economia da tecnologia do Brasil, Elsevier, Rio de Janeiro, RJ.

Yin, R. K. (2005), Estudo de caso, 3. ed., Bookman, Porto Alegre. 